\title{
The impact of water hyacinth manure on growth attributes and yields in Coriandrum sativum
}

\author{
N Lata ${ }^{1}$, Veenapani Dubey ${ }^{2}$ \\ ${ }^{1,2}$ Department of Botany, C.M.D. P.G. College, Gurughasi Das Vishwavidyalaya, India
}

\begin{abstract}
Experiment was conducted during 2007 and 2008 to study the effect of water hyacinth manure in comparison to control on Coriandrum sativum. Soil mineral analysis test was carried out for soil sample types. Added organic matter, water hyacinth manure in various combinations into soil has been found to influence the performance of crop plants as a result of the increase in nutrient availability. The observations revealed positive response with $100 \%$ water hyacinth manure, $50 \%$ water hyacinth manure and water hyacinth manure combined with farm yard manure on the growth behaviour of seedlings as they were enhanced significantly compared with that of the seedlings grown in control. The growth and productivity of Coriandrum sativum was more pronounced with $100 \%$ water hyacinth manure treatment.
\end{abstract}

Key words: Coriandrum sativum, Eichhornia crassipes, Manure, Water hyacinth, Yield

\section{Introduction}

One largely overlooked resource available for soil fertility remediation is the use of non-traditional organic materials such as weeds. The use of decayed tissues of unwanted plants to provide nutrients for crops is a crude but effective way of exploiting weeds and is a simpler technique than any of the other alternatives available. The use of nontraditional organic resources such as weeds for soil fertility improvement purposes has been studied by Sonke, Gachengo, Jama et al., Nziguheba et al., Chukwuka and Omotayo [1,2,3,4,5]. Thus, the studies have established the high potential of these resources in improving nutrient status and subsequent crop yield in soils amended by these resources. According to Beckman [6] the use of manure application enhances soil productivity, increases the soil organic carbon content, soil micro-organisms, improves soil crumb structure, the nutrient status of the soil and enhances crop yield. Organic manure is also very cheap and effective as a good source of nitrogen for sustainable crop production, but its availability remains an important issue due to its bulky nature, while inorganic fertilizer is no longer within the reach of poor-resource farmers due to its high cost [7].

Eichhornia crassipes (Mart.) Solms-Laubach commonly known as water hyacinth belonging to the family Pontederiaceae is listed as one of the most productive plants on the earth and is considered the world's worst aquatic weed $[8,9,10]$. Its habitat ranges from tropical desert to subtropical or warm temperate desert to rainforest zones. It tolerates annual temperatures ranging from $21.1^{\circ} \mathrm{C}$ to $27.2^{\circ} \mathrm{C}$ and its $\mathrm{pH}$ tolerance is estimated at 5.0 to 7.5 . The 'beautiful blue devil' water hyacinth, recognized by its lavender flowers and shinning bright leaves is a prolific aquatic plant, which spreads at an alarming rate. The plant is euryhaline, tolerating both fresh and marine water; hence its spread knows no boundaries. The so called "menace and nuisance" has tremendous potentiality of high rates of vegetative growth [11]. This macrophyte is one of the most invasive aquatic weeds in the world $[12,13]$ causing a serious hindrance to nations development activities. The plant is now considered as a serious threat to biodiversity. The possible ways of combating its proliferation and the various methods of eradicating this "weed" not proved much. All the efforts were in vein. Hence the present investigation aims towards the exploration of "best out of waste". Thus its utilization may become a way of its management.

Day [14] described the manorial value of water hyacinth especially in regard to its potash content, which is particularly high in the stalks. Singh and Yadav [15] also proved that different composts prepared from water hyacinth, mixed weeds, dry leaves and berseem increased yields of wheat, green beans and rice. This study was therefore carried out with the aim of finding the effect of water hyacinth manure on the production of the crop plant Coriandrum sativum. The investigation conducted to assess the positive effects of water hyacinth manure on crop yield and also to recommend an economical and feasible technology for farmers.

\section{Materials and Method}

An experiment was conducted at the field laboratory of the Department of Botany, CMD PG College, Bilaspur, India during the period of July to October 2007 and 2008. The general climate of the area is wet and humid, experiences hot summer and moderately cold winters, interspersed with rainy months. The annual potential evapo-transpiration is slightly higher than the annual rainfall. The monsoons are heavy between July and September in this region. 


\subsection{Exprimental Design and Treatments}

Water hyacinth manure was prepared during the rainy season at the campus (took 3 months and 10 days for the conversion of water hyacinth in to manure). Thus, obtained WHM (water hyacinth manure) was taken in varying combination such as 100\%WHM (whole water hyacinth manure, 1:0), 50\%WHM (water hyacinth manure + garden soil, 1:1), FYM'W (water hyacinth manure + farm yard manure in the ratio of 1:3) and CNTR (control where no water hyacinth manure but only garden soil is taken, $0: 1$ ). Soil mineral analysis test was carried out for soil sample types. Soil $\mathrm{pH}$ was taken using digital $\mathrm{pH}$ meter. Soil organic carbon was determined by the Walkley Black Modified method, while $\mathrm{Ca}, \mathrm{Mg}, \mathrm{K}, \mathrm{P}, \mathrm{Na}, \mathrm{Mn}, \mathrm{Cu}, \mathrm{Zn}$ and $\mathrm{Fe}$ were determined by the Mehlich-3 extraction procedure Mehlich [16]. Total nitrogen was analyzed by the Technicon AA II method [17]. Chemical composition of soil types are shown in Table 1 and 2.

The seeds of Coriandrum sativum were collected from the local market of Bilaspur. Only sound seeds were used to run the experiments. The selection of sound seeds was based on different morphological criteria such as colour, size and being uninfected. Seeds of test plant were sown equidistantly at the rate of 15 plants/labeled polythene bags of equal size and volume, filled with different soil treatments and were well perforated for aeration.

\subsection{Weather Conditions and Measurement of Plant Parameters}

The seeds of Coriandrum sativum were grown from July to October under atmospheric conditions with maximum and minimum temperature values 32.3 and $18.9^{\circ} \mathrm{C}$ respectively with relative humidity value of $85 \%$ within the study period. Annual rainfall range was between 984.8 and $1310.8 \mathrm{~mm}$. At maturity, a number of parameters were used to measure and evaluate the growth of Coriandrum sativum seedlings under different treatments [18]. These parameters include length of shoot, length of root, length of whole plant, number of inflorescence/plant, number of fruits/plant, fresh weight and dry weight of shoot, fresh weight and dry weight of root, dry weight of fruits, shoot/root ratio on fresh and dry weight basis.

\subsection{Statistical Assessment}

The experiments were repeated twice with three replicates. The data obtained were subjected to statistical analysis. Observations were presented in tabular form representing the Mean $\pm \mathrm{SD}$.

\section{Results}

Physiological behaviour of Coriandrum sativum when grown in different soil combinations were presented in the Table 3. Table 1shows the mineral composition of experimental soil and Table 2 reveals the chemical composition of Farm Yard Manure. Application of all combinations of water hyacinth manure had significant influence on the growth attributes and yield of the test plant when compared to control. A perusal of the data from Table 3 reveals that the maximum increase in above ground biomass were recorded in $100 \%$ WHM treatment followed by 50\% WHM and FYM'W treatment and minimum in control. High yield biomass was observed with 50\% WHM followed by 50\% WHM and FYM'W treatment and minimum in control. The results revealed that the plants grown in $100 \%$ WHM showed higher values for various growth parameters like length of root, fresh weight of shoot, dry weight of shoot and fresh weight of root over the plants treated with other combinations of soil (50\% WHM, FYM'W \& CNTR). The plants grown in 50\% WHM showed higher values in length of shoot, length of whole plant, number of inflorescence/plant, number of fruits/plant, d. wt. of root \& d. wt. of fruits/plant than the plants treated with other composition of WHM \& control. WHM (Water hyacinth manure) enhanced the yield (d. wt. of fruits) of crop plant Coriandrum sativum by $97.19 \%$. The plant showed best growth and yield performance with 50\% WHM treatment and may be arranged in the order as 50\% WHM $>100 \%$ WHM $>$ FYM'W $>$ CNTR.

Table1: Mineral composition of experimental soil

\begin{tabular}{lll}
\hline Parameters & A & B \\
\hline pH & 7.4 & 7.7 \\
Total Nitrogen (\%) & 0.161 & 0.83 \\
Available Phosphorous (ppm) & 55.72 & 97.64 \\
Potassium (C mol Kg-1) & 1.18 & 2.86 \\
Organic Carbon (\%) & 3.38 & 4.52 \\
$\mathrm{Ca}(\mathrm{Cmol} \mathrm{Kg-1)}$ & 31.72 & 48.83 \\
$\mathrm{Mg}(\mathrm{C} \mathrm{mol} \mathrm{Kg-1)}$ & 3.05 & 6.78 \\
$\mathrm{Na}(\mathrm{Cmol} \mathrm{Kg-1)}$ & 0.62 & 1.02 \\
$\mathrm{Zn}(\mathrm{ppm})$ & 2.71 & 3.2 \\
$\mathrm{Cu}(\mathrm{ppm})$ & 3.04 & 3.16 \\
$\mathrm{Mn}(\mathrm{ppm})$ & 231.78 & 268.54 \\
Fe (ppm) & 115.95 & 115.82 \\
\hline
\end{tabular}

A-Control Soil (CNTR), B- Water hyacinth manure (WHM) 
Table2: Chemical composition of Farm Yard Manure (FYM)

\begin{tabular}{lc}
\hline Composition & Values (\%) \\
\hline Total Nitrogen & 0.53 \\
Available Phosphorous & 0.28 \\
Potassium & 0.34 \\
Calcium & \\
\hline
\end{tabular}

Table 3: Growth parameters of Coriandrum sativum grown under different combinations of WHM

\begin{tabular}{|c|c|c|c|c|}
\hline Growth parameters & 100\% WHM & $50 \%$ WHM & FYM'W & CNTR \\
\hline Length of shoot $(\mathrm{cm})$ & $27.133 \pm 1.547$ & $29.05 \pm 1.906$ & $23 \pm 0.582$ & $19.3 \pm 0.813$ \\
\hline Length of root $(\mathrm{cm})$ & $10.85 \pm 1.007$ & $9.933 \pm 1.059$ & $7.1 \pm 0.561$ & $6.55 \pm 0.488$ \\
\hline Length of whole plant $(\mathrm{cm})$ & $37.983+2.418$ & $38.966+2.979$ & $30.1+1.420$ & $25.85 \pm 2.212$ \\
\hline No. of inflorescence/plant & $11.833 \pm 2.935$ & $12.666 \pm 3.477$ & $4.666 \pm 0.950$ & $4.166 \pm 0.692$ \\
\hline No. of fruits/plant & $16.166 \pm 0.692$ & $20.666 \pm 3.891$ & $10.833 \pm 2.359$ & $8 \pm 1.646$ \\
\hline F.wt. of shoot (mg) & $0.478 \pm 0.207$ & $0.465 \pm 0.149$ & $0.405 \pm 0.081$ & $0 . \overline{248 \pm 0.093}$ \\
\hline D.wt. of shoot (mg) & $0.298 \pm 0.066$ & $0.288 \pm 0.101$ & $0.145 \pm 0.034$ & $0.116+0.044$ \\
\hline F.wt. of root (mg) & $0.0516 \pm 0.035$ & $0.043 \pm 0.019$ & $0.013 \pm 0.004$ & $0.016 \pm 0.009$ \\
\hline D.wt. of root (mg) & $0.018 \pm 0.010$ & $0.026 \pm 0.012$ & $0.008 \pm 0.003$ & $0.01 \pm 0.005$ \\
\hline D.wt. of fruits (mg) & $0.175 \pm 0.059$ & $0.178 \pm 0.054$ & $0.077 \pm 0.023$ & $0.005 \pm 0.001$ \\
\hline $\mathrm{S} / \mathrm{R}$ ratio (F.wt. basis) & 9.3 & 10.81 & 31.15 & 15.5 \\
\hline S/R ratio (D.wt. basis) & 16.5 & 11.07 & 18.12 & 11.6 \\
\hline
\end{tabular}

$[$ Mean \pm S.D. $(n=60)]$

Key : WHM is Water Hyacinth Manure ; 100\% WHM is whole water hyacinth manure (1:0); $50 \%$ WHM is $50 \%$ water hyacinth manure $+50 \%$ garden soil $(1: 1)$; FYM'W is $25 \%$ water hyacinth manure $+75 \%$ farm yard manure (1:3); CNTR is whole garden soil as control $(0: 1)$; S/R is Shoot / Root; F.wt. is Fresh weight; D.wt. is Dry weight

\section{Discussion}

Efforts at remediating soil fertility over the years have basically been achieved using traditional resources of farmyard manure and crop residues in composted forms as well as use of inorganic fertilizer [20].

Weed however; have been recognized to have significant effects on sustainability of soil nutrient resources and yield of agricultural produce [20]. The benefit of using either crop residues such as water hyacinth residues has been reported by Widjajanto et al. [21,22]. The study of water hyacinth as biofertilizer revealed that the incorporation of water hyacinth into soil crop system increased the performance yield of the crop plant Coriandrum sativum. Water hyacinth manure (WHM) in all combinations was found to be more effective for the growth and yield of the test plant over the control. Majid [23] have reported enhancement in yield/plant in rice, corn, sesame, brinjal, onion and gourd, using Water hyacinth compost. Majid et al. \& Majid $[24,25]$ reported the increased yield in above plants with both compost as well as manure of Water hyacinth used in combination with other aquatic weeds. Our results are in agreement with previous works [26,27,21].

Widjajanto et al. [28] reported the increased performance of Brassica rapa by the incorporation of Water hyacinth into soil-crop systems. Gunnarssen \& Petersen [29] also highlighted that using composted Water hyacinth material could serve as quality manure for improving soil fertility conditions and thus crop yields on the whole. Enhanced affects of Water hyacinth have been reported by Kayum et al. [30] on productivity of tomato and Amitava et al. [31] on rice. Chukwuka \& Omotayo [5,32] indicated the soil fertility potential of Water hyacinth compost and revealed its enhanced affect on productivity of Zea mays crop. With this result it can be suggested that, by the addition of Water hyacinth manure into cultivation which affected the performance of test plant may be probably due to the increase of Nitrogen availability released from Water hyacinth during the process of mineralization. This is in agreement with Contantinides \& Fownes [33] who mentioned that quality and quantity of added organic materials into soil may influence the decomposition rate and mineralization process. The same phenomenon was also reported by Widjajanto et al. [21].

\section{Conclusion}

The decayed tissues of "beautiful blue devil" as soil amendment in its crude form found to be very effective by enhancing the soil productivity and yield of crop plant. Due to this positive effect on crop yield use of WHM is an economical and feasible technology for farmers.

\section{Vi Acknowledgement}

The author (NL) is very thankful to Dr. Mrs. Veenapani Dubey, (Prof. and Head of Department of Botany C. M. D. P. G. College Bilaspur) and Dr. M. Sellote (Rtd. Prof. and Head of Department of Botany C. 
M. D. P. G. College Bilaspur) for their constant guidance and providing all facility. Author NL is the main author performed experimental work, data observation and collection, literature survey, drafting and finalized the manuscript. Author VPD supervised the research work.

\section{References}

[1] D Sonke, Tithonia weed a potential green manure crop, Echo. Dev. Notes. 57, 1997, 5-6.

[2] C.N. Gachengo, Phosphorus release and availability on addition of organic materials to phosphorus fixing soils. M. Sc. Thesis, Moi University, Eldoret, Kenya, 1996.

[3] B Jama., C. A. Palm, R. J. Buresh, A. Niang, C. Gachengo, G. Nziguheba and B. Amadalo, Tithonia diversifolia, a green manure for soil fertility improvement in western Kenya: Areview, Agro. For. Syst, 49, 2000, 201-221.

[4] G Nziguheba, R. Merckx, C. A. Palm and P. Mutuo, Combined uses of Tithonia diversifolia and inorganic fertilizers for improving maize production in a phosphorus deficient soil in western Kenya, Agro. For. Syst, 55, 2002, 165-174.

[5] K.S. Chukwuka and O. E. Omotayo, Effects of Tithonia Green Manure and Water Hyacinth Compost Application on Nutrient Depleted Soil in South-Western Nigeria, International Journal of Soil Sciences, 3(2), 2008, 69-74.

[6] E. O. Beckman, Organic fertilization: vegetable farming luxury or necessity, Tech. Commun. ISHA., $29,1973$.

[7] S. A. Rahman, The place of organic manure in sustaining agricultural development in Nigeria. Paper presented at science technology and society national workshop in Lafia, Nasarawa state, $11^{\text {th }} \mathrm{July}, 2004$.

[8] L. G. Holm, D. L. Plucknett, J. V. Pancho and J. P. Herberger, The world's worst weeds: Distribution and biology (Honolulu: University Press of Hawaii, 1977).

[9] H.E Westerdahl and K. D. Getsinger, Aquatic Plant identification and herbicide use guide, Volume II: Aquatic plants and susceptibility to herbicides. Technical report A-. Department of the Army, Waterways Experiment Station, Corps of Engineers, Vicksburg, MS, 1988, 9-88

[10] M. J. Grodowitz, An active approach to the use of insect biological control for the management of non-native aquatic plants, J. Aqua. Plant. Manage, 36, 1998, 57-61.

[11] W. T Penfound and T. T. Earle, Biology of water hyacinth, Ecol. Monogr, 18, 1948, 449.

[12] U.S.EPA, Design manual-constructed wetlands and aquatic systems for municipal waste water treatment. U.S.Environmental Protection Agency. Report No. EPA/625/1-88/022. Office of Research and Development, Cincinnati, OH, 1988, 83

[13] M. A. Maine, N. L. Sune, M. C. Panigatti and M. J. Pizarro, Relationships between water chemistry and macrophyte chemistry in lotic and lentic environment, Arch. Hydrobiol, 145(2), 1999, 129-145.

[14] F. W. F. Day, Water hyacinth as a source of potash, Agric. Bull., Fed Malay States, 6(7/8), 1918

[15] R. D. Singh and D. V. Yadav, Evaluation of low grade rock phosphate composted with some agricultural wastes for use in a crop rotation, Agri. Wastes, 18(1), 1986, 73-79.

[16] M. Mehlich, Mehlich-3 soils test extractant: A modification of the Mehlich 2 extractant, Comm. Soil Sci, Plant Anal, 15, 1984, 1409-1416.

[17] IITA, Automated and semi automated methods for soil and plant analysis (Manual series No. 7, Ibadan-Nigeria: International Institute for Tropical Agriculture (IITA), 1982).

[18] R. Mishra, Ecology workbook (New Delhi: Oxford IBH pub. co, 1968).

[19] M. K. C. Sridhar and G. O. Adeoye, Organo-mineral fertilizers from urban wastes: development in Nigeria, The Nigerian Field, 68(2), 2003, 91-111.

[20] O. I. Oyetunji, I. J. Ekanakaye and O. Osonubi, Influence of arbuscular mycorrhizae fungus, mulch and fertilizer application on yield of-yams in an agroforestry system in South Western Nigeria, Maurik. Bull, 6, 2003, 75-82.

[21] D. W. Widjajanto, K. Matsushila, T. Honmura and N. Miyanch, Studies on the release of N from water hyacinth incorporated into soil-crop systems using ${ }^{15} \mathrm{~N}$-labeling teachniques, Pak. J. Biol. Sci., 4, 2001, 1075-1077.

[22] D. W. Widjajanto, T. Honmura and N. Miyanch, Nitrogen release from green manure of water hyacinth in rice cropping systems, Pak. J. Biol. Sci., 5, 2002, 740-743.

[23] F. Z. Majid, Aquatic weeds and algae, the neglected natural resources of Bangladesh. Booklet, $1983,26$.

[24] F. Z. Majid, N. Lutfun, B. Sajeda, K. Rahima and N. Akhatar, Use of naturally occurring algae as biofertilizer or organic manure, Proc. $26^{\text {th }}$ National Workshop on Algal systems, Madras, India, 1980, 11-14

[25] F. Z. Majid, Utility and development, in S.S.Purohit (Ed), Aquatic weeds (India: AgroBotanical, India, 1992)

[26] R. A. Morris, R. E. Furoc and M. A. Dizon. Rice responses to a short duration green manure. II. Recovery Utilization, Agron. J., 78, $1986,413-416$.

[27] G. H. Harris, O. B. Hesterman, E. A. Paul and R. R. Janke, Fate of legume and fertilizer nitrogen-15 in a long-term cropping system experiment, Agron. J., 86, 1994, 910-915.

[28] D. W. Widjajanto, T. Honmura and N. Miyanch, Nitrogen dynamics in Komatsuna (Brassica rapa) cultivation due to incorporation of water hyacinth residues into the system, Pak. J. Biol. Sci., 6(1), 2003, 10-15.

[29] C. C. Gunnarsson and C. M. Petersen, Water hyacinth as a resource in agriculture and energy production: A literature review, Waste Manage., 27, 2006, 117-129.

[30] M. A. Kayum, M. Asaduzzaman and M. Z. Haque Effects of Indigenous Mulches on Growth and Yield of Tomato, J. Agric. Rural. Dev., 6(1-2), 2008, 1-6.

[31] R. Amitava, N. C. Sarkar and S. Debashish, Influence of organic manures on productivity of two varieties of rice, J. Cent. Eur. Agric., 9(4), 2008, 629-634.

[32] K. S. Chukwuka and O. E. Omotayo, Soil fertility restoration potentials of Tithonia green manure and water hyacinth compost on a nutrient depleted soil in South Western Nigeria using Zea mays L. as test crop, Res. J. Soil. Biol., 1(1), 2009, $20-30$.

[33] M. Contantinides and J. H. Fownes, Nitrogen mineralization from leaves and litter of tropical plants: Relationship to nitrogen, lignin and soluble polyphenol concentrations, Soil. Biol. Biochem., 26, 1994, 49-55. 